\title{
Screening of grapevine red blotch virus in two European ampelographic collections
}

\author{
Jean-Sébastien Reynard ${ }^{1}(1) \cdot$ Justine Brodard ${ }^{1} \cdot$ Nathalie Dubuis $^{1} \cdot$ Isabelle Kellenberger ${ }^{1} \cdot$ Anne-Sophie Spilmont $^{2}$. \\ David Roquis $^{1}$ - Varvara Maliogka ${ }^{3} \cdot$ Cécile Marchal $^{4} \cdot$ Sandrine Dedet $^{4} \cdot$ Ophélie Gning $^{5} \cdot$ Daniel Croll $^{5}$. \\ Katia Gindro ${ }^{1} \cdot$ Olivier Schumpp ${ }^{1} \cdot$ Jean-Laurent Spring ${ }^{1} \cdot$ Thierry Lacombe $^{6}$
}

Received: 23 February 2021 / Accepted: 1 October 2021 / Published online: 12 November 2021

(c) The Author(s) 2021

\begin{abstract}
Grapevine red blotch virus (GRBV) is a recently identified virus that infects grapevine and has a severe impact on the grape industry in North America. Since the first description of the virus 8 years ago, clear progress has been made regarding our understanding of the GRBV pathosystem. However, questions remain regarding the origin of this pathogen and its spread outside North America, especially in Europe. In this study, we present the results of a large-scale GRBV survey in two European repositories; we targeted Vitis spp. accessions with diverse geographical origins. Of 816 accessions from different origins (50 different countries around the world), six accessions were infected by GRBV, all of which originated from the United States. We investigated the DNA virome of 155 grapevine accessions from the Swiss grapevine collection using high-throughput sequencing. We observed that virome of the Swiss grapevine collection was composed of several RNA viruses. In contrast, we did not detect any DNA viruses in the 155 Swiss grapevine accessions. This finding suggests that the abundance of DNA viruses infecting grapevines in Switzerland is either very low or non-existent. Our results and the findings of studies published since 2008 show that GRBV most likely originated in North America and subsequently spread to other viticultural areas in the world via unintentional movement of infected cuttings. According to our data, the most plausible scenario for the origin of GRBV is that the virus evolved from non-Vitis vinifera hosts and underwent a host jump to Vitis vinifera after its introduction to North America in the 1600s.
\end{abstract}

Keywords Grapevine red blotch virus · Vitis vinifera $\cdot$ Large-scale survey

\section{Introduction}

Grapevine is susceptible to a variety of pathogens. Among these pathogens, viruses are intracellular agents that can be responsible for severe diseases. To date, more than

Jean-Sébastien Reynard

jean-sebastien.reynard@agroscope.admin.ch

Route de Duillier, 1260 Nyon, Switzerland

2 IFV, Domaine de l'Espiguette, 30240 Le Grau du Roi, France

3 Plant Pathology Laboratory, School of Agriculture, Aristotle University of Thessaloniki, 54124 Thessaloniki, Greece

4 Grapevine Biological Resources Center, INRAE, Unité Expérimentale Domaine de Vassal, University of Montpellier, 34340 Marseillan, France

5 Laboratory of Evolutionary Genetics, Institute of Biology, University of Neuchâtel, CH-2000 Neuchâtel, Switzerland

6 AGAP, University of Montpellier, CIRAD, INRAE, Institut Agro, Montpellier, France
80 different viruses have been reported to infect grapevine worldwide (Fuchs 2020). In fact, grapevine has been reported to be the plant infected with the greatest number of different viruses to date (Fuchs 2020). The most economically relevant viruses belong to the families Secoviridae (fanleaf viruses), Closteroviridae (leafroll viruses), and Betaflexiviridae (rugose wood associated viruses). These viruses are present worldwide and might cause important negative impacts, such as shortening the productive life of vineyards and reducing the quality and yield of the harvest. In contrast to these viral diseases, which have been described since at least the beginning of the last century, emerging viruses have only recently been identified. Red blotch disease is caused by such an emerging virus and was identified only recently in 2008 in Napa Valley (California) (Calvi 2011). In 2012, grapevine red blotch virus (GRBV) was discovered independently in California and New York (Al Rwahnih et al. 2012; Krenz et al. 2012) and was later determined to be the causal 
agent of red blotch disease when Koch's postulates were demonstrated (Yepes et al. 2018). Red blotch disease can cause detrimental effects on plant physiology, reducing vine vigour and disrupting gas exchange (Levin and $\mathrm{KC}$ 2020; Reynard et al. 2017). Delayed fruit ripening and reduced fruit and wine quality have been reported to be a consequence of red blotch disease (Blanco-Ulate et al. 2017; Ricketts et al. 2017). Red blotch is an emerging viral disease that has a severe impact on the grape industry in North America (Sudarshana et al. 2015). Given the significant economic consequences of this virus, it has been the subject of considerable research efforts since its discovery, which have led to clear progress in our understanding of the pathosystem. However, questions remain regarding the origin of this pathogen and its spread outside North America, especially in Europe. In this study, we present the results of a large-scale GRBV survey targeting Vitis spp. accessions with diverse geographical origins in two European repositories, one in Switzerland and the other in France. The French collection of INRAE Domaine de Vassal near Montpellier is well suited to address the question of the spread of GRBV outside North America, since it is one of the oldest and largest Vitis vinifera repositories worldwide. Our findings showed that very few accessions were infected by GRBV, and all of them had North American origins. Based on our results, we discussed various scenarios for the origin of GRBV in Vitis vinifera.

\section{Materials and methods}

\section{Plant material}

The study was performed in two national grapevine repositories: one at Agroscope in Pully (VD) in Switzerland and one at INRAE in the Domaine de Vassal near Montpellier in France. The Swiss grapevine collection is an international reference for varieties grown under alpine conditions (Fahrentrapp et al. 2015). This collection contains over 450 different accessions, and most of the collected varieties have a European origin and belong to Vitis vinifera. The INRAE Vassal-Montpellier Grapevine Biological Resources Center (www.montpellier.inrae.fr/ vassal), which is located near Montpellier in LanguedocRoussillon in France, cultivates the largest living range of vines in the world with several thousand copies. These vines include 2,300 cultivars obtained from more than 50 different countries. For this study, accessions were sampled according to their country of origin to obtain 1) all the accessions imported/originated from the USA and 2) a representative sampling of the other countries (Supplementary Table S1).

\section{GRBV detection}

Infected control plants were used as the GRBV reference and were collected from the Agroscope grapevine virus collection. These plants were used as positive controls for the analytical tests. GRBV detection was performed for every sample by two assays. The first assay was an endpoint PCR test (Krenz et al. 2014), and the second was a real-time PCR test, as commercialized by Bioreba AG, Switzerland (Reynard et al. 2018). In addition to the primers utilized in these assays for virus detection, primers targeting a plant internal control were added to the reaction. PCR assays were performed as described in the relevant publication (Krenz et al. 2014, Reynard et al. 2017). Samples for the surveys consisted of three petioles from basal leaves collected from two separate canes of a vine during the summer months of 2017 and 2019. Collected petioles were maintained at $-20{ }^{\circ} \mathrm{C}$ until further processing. DNA was extracted from petioles using a rapid CTAB procedure (Reynard et al. 2017). Based on previous tests with GRBV references, both diagnostic assays were shown to consistently detect one infected individual vine when present in a composite sample consisting of 10 vines. Therefore, to reduce the analysis cost, a composite sampling strategy was used: petioles from ten different vines were combined for DNA extraction. When a composite sample produced a positive signal, the 10 petioles representing individual vines were extracted and tested separately.

To obtain the complete GRBV genome of the accession Husseini 2904Mtp1, we used the "mobilome" method by Lanciano et al. (2017), which was developed to enrich samples in circular DNA, with minor modifications. In brief, $2 \mu \mathrm{g}$ of DNA extracted using a rapid CTAB procedure from infected leaves was digested with 10 units of PlasmidSafe (LubioScience cat\# E3101k) for $4 \mathrm{~h}$ at 37 ${ }^{\circ} \mathrm{C}$. PlasmidSafe digests linear double stranded DNA but is less efficient on linear or circular single stranded DNA molecules, such as the GRBV genome and other extrachromosomal circular DNA from the plant. The digestion product was later precipitated with isopropanol and processed through rolling circle amplification (RCA) following the manufacturer's protocol of the Illustra TempliPhi (GE Health Care Life Science cat\# 25640010). RCA is used to specifically amplify circular DNA. TempliPhi products were precipitated in ethanol, resuspended in water, and then sequenced on a Nanopore Minion Mk1C using an R9 flow cell and a rapid barcoding sequencing kit (Nanopore cat \# SQK-RBK004) following the manufacturer's protocol. Sequences from the Minion were base called, and adapter sequences were trimmed with Guppy v3.4.5 using the built-in configuration "dna_r9.4.1_450bps_fast.cfg". Reads were subsequently processed through Filtlong v0.2.0 (https://github.com/ 


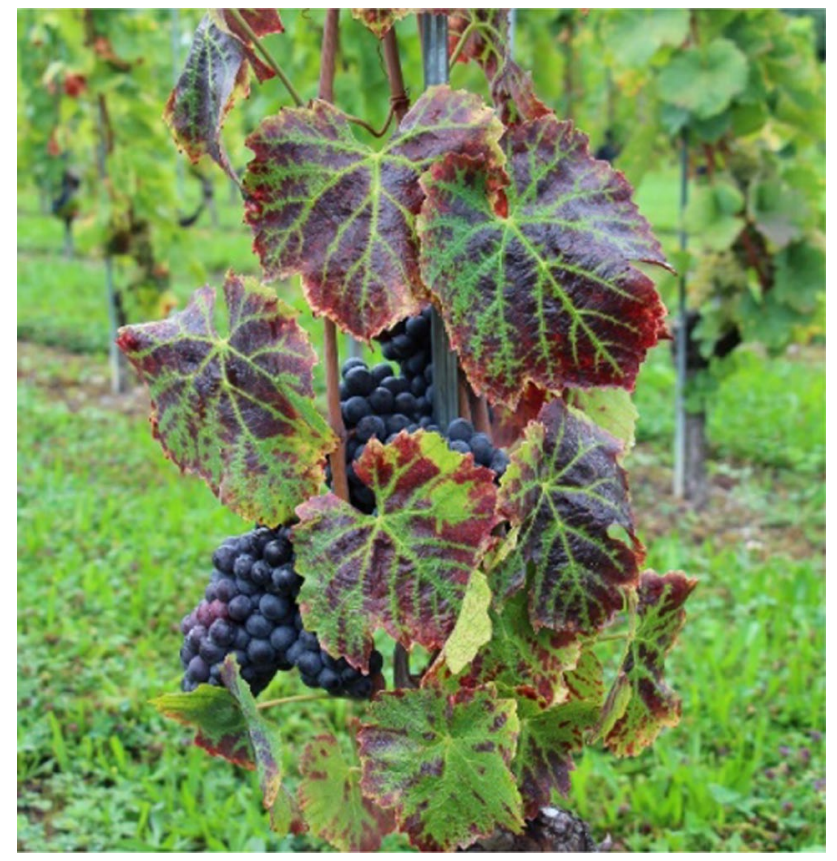

Fig. 1 Red blotch leaf symptoms on Vitis vinifera cv. Gamay at harvest in 2014 in the Swiss grapevine collection. No leafroll viruses were detected in this accession. Reddening symptoms are not very specific and could easily be overlooked

rrwick/Filtlong) with --min_mean_q 80 and --min_length 200 to remove low-quality sequences. Next, reads were assembled in circular assemblies with Unicycler v0.4.8 using default parameters (Wick et al. 2017). Assembled contigs were subsequently screened to find identity with GRBV known sequences using NCBI Blast+ suite v2.6.0 (Camacho et al. 2009).

\section{Whole-genome resequencing and RNA virus detection:}

A total of 155 accessions were obtained from the Swiss national grapevine repository in Pully (see Supplementary Table S2), and two DNA virus-infected references were obtained from the Agroscope virus collection. Mature leaves were collected in July 2019. Total DNA was extracted using lyophilized material and a CTAB protocol (Reynard et al. 2017). Two micrograms of genomic DNA from each accession was used to construct a sequencing library, which was then subjected to paired-end sequencing $(2 * 150 \mathrm{bp})$ on an Illumina HiSeq 4000 at Novogene UK (https://en.novogene. com). For a total of 157 accessions, approximately $20 \mathrm{~Gb}$, or 70-90 million paired-end reads, of genomic data were obtained. The reads were subsequently mapped to the genome of Vitis vinifera (PN40024 12X v2) using bwa mem (Version: 0.7.17-r1188, (Li and Durbin 2009)) with the default parameters. Unmapped reads were assembled de novo using SPAdes (Bankevich et al. 2012). Finally, contigs were annotated using blastn/blastx (Camacho et al. 2009) against reference sequences for virus identification (June 2020).

To assess RNA virus infection in the Swiss ampelographic repository, some common RNA viruses were tested using enzyme-linked immunosorbent assay (ELISA). Commercially available ELISA kits (Bioreba AG, Switzerland) were used according to the manufacturer's instructions.

\section{Results}

Symptoms of red blotch disease cause red patches on leaves in black berry cultivars (Fig. 1), similar to the symptoms caused by leafroll disease. Based only on visual inspection, it is difficult to differentiate leafroll and red blotch disease (Sudarshana et al. 2015). Therefore, symptoms are not highly specific, and GRBV infection can be easily overlooked based only on visual inspection. For this reason, an analytical approach was used in this work to assess GRBV presence. From the Swiss national repository, 164 accessions were selected randomly to be monitored for GRBV infection using PCR. All these samples tested negative for GRBV. In the French national repository, 652 accessions were selected for GRBV screening to represent the diversity of geographical origin present in this collection (North America: 297; South America: 32, Europe: 205; Africa: 25; Asia: 71 and Oceania: 22). Six of those 652 accessions were found to be infected by GRBV (Table 1). Since most of these accessions were coinfected by leafroll viruses, it was not possible to infer GRBV infection based on visual inspection. Following a careful inspection

Table 1 Accessions from the French national repository in Vassal infected by grapevine red blotch virus (GRBV)

\begin{tabular}{lllll}
\hline Cultivar (ID) & Cultivar origin & Accession name (ID) & Imported from & Introduction year \\
\hline Hopkins faux (6812) & USA & Hopkins faux (5000Mtp55) & USA & before 1950 \\
Cloeta (6805) & USA & Cloeta (5000Mtp21) & USA & before 1950 \\
Kandahar (2908) & Afghanistan & Kandahar (2908Mtp1) & Australia (<-USA) & 1982 \\
Ruby Cabernet (2313) & USA & Ruby Cabernet (2313Mtp1) & USA & 1962 \\
Beta (6606) & USA & Xinta (5000Mtp127) & USA & before 1950 \\
Abjouch (1748) & Afghanistan & Husseini (2904Mtp1) & Australia (<-USA) & 1982 \\
\hline
\end{tabular}


Table 2 RNA virus survey using enzyme-linked immunosorbent assay (ELISA) in the Swiss grapevine repository: grapevine fanleaf virus (GFLV), Arabis mosaic virus (ArMV), strawberry latent rings- pot virus (SLRSV), grapevine fleck virus (GFkV), grapevine leafrollassociated viruses (GLRaV-1, -2, -3, -4)

\begin{tabular}{lllllll}
\hline & Virus & & & \\
\cline { 2 - 6 } & GFLV/ArMV & SLRSV & GFkV & GLRaV-1/-3 & GLRaV-2 & GLRaV-4 \\
\hline Number of analysed accessions & 237 & 237 & 160 & 240 & 237 & 237 \\
Number of infected accessions & 33 & 2 & 26 & 79 & 13 & 5 \\
Ratio of infected accession & $14 \%$ & $1 \%$ & $16 \%$ & $32 \%$ & $5 \%$ \\
\hline
\end{tabular}

of the archives of the Vassal collection, we knew that those infected accessions had never been sent to other repositories in France or worldwide. Subsequently, all plants surrounding the infected accessions in the Vassal collection were sampled and analysed for GRBV infection, and they tested negative. The six infected accessions were destroyed and eliminated from the repository directly after confirming their GRBV infection status.

Regarding the origin of the infected accessions, four were directly imported from the USA, of which three were introduced in the first half of the 20th century (Table 1). The remaining two accessions, Kandahar (2908Mtp1) and Husseini (2904Mtp1), were imported and introduced to the Vassal collection in 1982 from an Australian germplasm collection. However, according to the records, those two accessions had been previously introduced to Australia via a direct import from the USA.

To further characterize the GRBV isolate infecting the Husseini accession (2904Mtp1) from Vassal collection, the full-genome sequence of this isolate was obtained. GRBV Husseini is highly similar (nt identity: 99.3\%) to the originally reported GRBV sequence (Krenz et al. 2012).

Grapevine viruses are frequently observed in commercial vineyards (Reynard and Gugerli 2012). The majority of grapevine viruses described to date have positive singlestranded RNA genomes. Our small survey in the Swiss grapevine repository of some well-known RNA grapevine viruses confirmed the presence of these RNA viruses (Table 2).

We used high-throughput sequencing techniques to assess the presence of DNA viruses in the Swiss ampelographic collection. We followed a whole genome resequencing approach and included two positive control plants to verify the performance of our method. The two control viruses were grapevine Roditis leaf discoloration-associated virus and grapevine red blotch virus, representatives of DNA viral families known to infect Vitis spp. In both cases, the viral signal was present and could be easily detected using our pipeline, validating the method we were using (Table 3). However, we found no evidence of DNA virus infections in any of 155 tested samples.

\section{Discussion}

Previous surveys demonstrated a high prevalence of GRBV in all major grape-growing regions across the USA (Krenz et al. 2014). The virus was reported in commercial vineyards in other countries in the Americas, including Canada (Poojari et al. 2017), Mexico (Gasperin-Bulbarela et al. 2019) and Argentina (Luna et al. 2019). Reports on GRBV infecting cultivated grapevines in South Korea (Lim et al. 2016) and in India (Marwal et al. 2019) suggest the potential spread of GRBV in Asia even though the origin of the infected plants is not known. No report has been published on GRBV infections in commercial vineyards in Europe. Recent surveys conducted in Switzerland by Reynard et al. 2017 reported the absence of GRBV from Swiss vineyards, but the virus was detected in a grapevine virus collection of 6 accessions, all originating from the USA.

In this study, we present the results of the largest sampling effort to date regarding the geographical origin of GRBV-infected samples. In this work, 816 Vitis spp. accessions with different geographic provenience were analysed, and we identified 6 infected accessions, all of which had a US origin. The results of our survey sharply contrast with

family Geminiviridae) and another infected by grapevine Roditis leaf discoloration-associated virus (GRLDaV, a member of the family Caulimoviridae)
Table 3 Virus detection by whole-genome resequencing of reference infected grapevines. Two reference infected plants were analysed; one was infected by grapevine red blotch virus (GRBV, a member of the

$$
\text { \# total paired reads }
$$

\# viral read/genome coverage/average mapping depth

GRBV infected reference

$80^{\prime} 880^{\prime} 180$

GRLDaV infected reference

$73 ‘ 372 ‘ 632$

$42^{\prime} 860 / 100 \% / 2{ }^{\prime} 003 \mathrm{x}$

2 '793/100\%/58x 
what has been reported during a similar survey in the USA (Al Rwahnih et al. 2015b), where 156 accessions were tested in the National Clonal Germplasm Repository in California, and 73 accessions originating from major grape-producing countries (e.g., France, Italy, and Spain) were infected by GRBV. It was not known in 2015 if those accessions were already infected at the time of their introduction in the USA. In light of the information gathered in subsequent years, infections of European material in North America reported by Al Rwahnih et al. 2015b should rather be considered as having occurred after the introduction of the corresponding materials in American repositories.

Some infected accessions found in the Vassal collection were in the field for extended periods of time ( $>70$ years). Therefore, to test the putative spread of the virus in the collection, all plants surrounding the infected accessions were carefully analysed for the presence of GRBV. No sign of GRBV spread was found in the Vassal repository. Similar to what has been reported in a Swiss virus grapevine repository (Reynard et al. 2017), the absence of field transmission could be explained by the absence of a vector. In North America, the three-cornered alfalfa hopper, Spissistilus festinus, has been reported as a vector of GRBV (Bahder et al. 2016a) and transmission occurs in a circulative, nonpropagative mode (Flasco et al. 2021). This insect has not been reported to date in Europe.

No virus other than those with an RNA genome had been reported on grapevine up to 2011 when the first DNA genome virus was described (Zhang et al. 2011). To date, eight viruses among the 86 reported on grapevine (Fuchs 2020) have a genome consisting of DNA. These eight viruses belong taxonomically to two different families: i) Geminiviridae: grapevine begomovirus A, grapevine red blotch virus, wild Vitis latent virus 1, grapevine geminivirus A, temperate fruit-decay-associated virus and ii) Caulimoviridae: grapevine vein clearing virus, grapevine badnavirus 1, grapevine Roditis leaf discoloration-associated virus. We applied high-throughput sequencing to study the DNA part of the grapevine virome in Switzerland. The first application of HTS in grapevine virology began in 2009 (Al Rwahnih et al. 2009). In subsequent years, this technique has completely revolutionized plant virus discovery and diagnosis (Maree et al. 2018; Massart et al. 2017). The main advantage of this technology is that it enables characterization of the different viruses infecting a plant with a minimal requirement of a priori knowledge on the infecting viruses. In conclusion, in contrast to RNA viruses, these results indicate that DNA viruses were absent in our sampling material. This finding implies either an absence of DNA viruses infecting grapevines in Switzerland or putative presence at a low frequency not detected by our sampling strategy.
Regarding the origin of GRBV, two hypotheses were proposed by Cieniewicz et al. (2017). The first hypothesis postulates a global distribution of the virus at a low infection rate. According to this hypothesis, given the low occurrence, the virus would normally not be associated with a sufficient level of disease having the consequence of becoming unnoticed except in the USA, where the virus would have spread to the point of detection. A second hypothesis proposed a North American origin for GRBV. The following points tend to invalidate the first hypothesis while favouring the second. i) Given the DNA viral genome data gathered using HTS on Swiss accessions, DNA viruses seem to be absent from Vitis vinifera in Switzerland or are at best rare. Given the central location of Switzerland in Europe and the extensive exchange of Vitis germplasm, we could reasonably assume that the Swiss conditions are a good proxy for the status of Vitis vinifera in Western Europe. The situation in USA regarding GRBV is different. Another virus, wild Vitis virus 1, taxonomically close to GRBV (both belonging to the same genus Grablovirus), was reported in wild grapevines from Napa County in California (Perry et al. 2017). Furthermore, GRBV was demonstrated to circulate between cultivated areas and wild ecosystems, since free-living vines were shown to harbour GRBV (Bahder et al. 2016b; Perry et al. 2016). This finding indicates that a mechanism, which is not man-mediated, is able to move the virus between both cultivated and wild compartments. ii) A survey of 2,700 commercial vines in Switzerland did not reveal the presence of GRBV (Reynard et al. 2017). iii) The results presented in this report on GRBV testing of large germplasm collections with diverse geographical origins, highlighted that GRBV infection showed a clear USA origin. iv) Eight years after the discovery of the virus in the USA, no GRBV infection has been reported in commercial vineyards in any grape production country of Europe. In contrast, the virus is widespread throughout some of the major grape-growing regions of the USA, and all characterized GRBV isolates to date show a North American origin.

In summary, research conducted since the discovery of the virus showed that GRBV most likely originated in North America and subsequently spread to other viticultural areas in the world via unintentional movement of infected cuttings. A plausible scenario for GRBV origin would be that the virus has evolved from infected non-Vitis vinifera hosts and at some point made a host jump, which was enabled by polyphagous insect vectors, into Vitis vinifera after its introduction to North America in the 17th century. Similar scenarios have been suggested for other grapevine pathogens. For example, Flavescence dorée, a European quarantine grapevine disease, is caused by a phytoplasma that is considered 
to have originated from European alders (Malembic-Maher et al. 2020).

Furthermore, the virus was already circulating around the globe before the 1950s, as demonstrated by our finding that GRBV-infected material was imported from the USA to Europe before the 1950s in three instances (Table 1). This result confirms previous findings showing that although the virus was only recently described, it has been present in California for an extended period, as attested by the presence of GRBV in Vitis vinifera cv. Early Burgundy stored in an herbarium assembled in 1940 from California vineyards (Al Rwahnih et al. 2015a). GRBV has been overlooked for decades because of the lack of a detection test and because it causes symptoms similar to those of leafroll disease; therefore, GRBV is not a recently emerging virus.

In conclusion, our results support the possibility that GRBV originated in North America. Given the economically important detrimental effects of GRBV infections, this virus should be considered a quarantine pathogen for regions where the virus is absent from commercial vineyards. Furthermore, this study demonstrates the importance in ampelographic collections throughout the world to perform GRBV testing and destroy infected plants in order to rule out any risk of dissemination of this damaging pathogen to adjacent grape production areas.

Supplementary information The online version contains supplementary material available at https://doi.org/10.1007/s42161-021-00952-9.

Acknowledgements Sequencing of GRBV accession Husseini was supported by the ERC grant Bungee from the European Research Council (Dr. Etienne Bucher). Whole-genome sequencing of the grapevine accessions was supported by the Federal Office for Agriculture through the national action plan to conserve valuable plant genetic material (grant RPGAA-NN-0044).

Funding Open access funding provided by Agroscope

\section{Declarations}

Ethical approval This article does not contain any studies requiring ethical approval.

Conflict of interest All authors have no conflict of interest.

Open Access This article is licensed under a Creative Commons Attribution 4.0 International License, which permits use, sharing, adaptation, distribution and reproduction in any medium or format, as long as you give appropriate credit to the original author(s) and the source, provide a link to the Creative Commons licence, and indicate if changes were made. The images or other third party material in this article are included in the article's Creative Commons licence, unless indicated otherwise in a credit line to the material. If material is not included in the article's Creative Commons licence and your intended use is not permitted by statutory regulation or exceeds the permitted use, you will need to obtain permission directly from the copyright holder. To view a copy of this licence, visit http://creativecommons.org/licenses/by/4.0/.

\section{References}

Al Rwahnih M, Daubert S, Golino D, Rowhani A (2009) Deep sequencing analysis of RNAs from a grapevine showing Syrah decline symptoms reveals a multiple virus infection that includes a novel virus. Virology 387:395-401. https://doi.org/10.1016/j. virol.2009.02.028

Al Rwahnih M, Dave A, Anderson M, Uyemoto J, Sudarshana MR (2012) Association of a circular DNA virus in grapevines affected by red blotch disease in California Proc 17th Congr Int Counc Study Virus Virus-like Dis Grapevine (ICVG), Davis, US: $104-105$

Al Rwahnih M, Rowhani A, Golino D (2015a) First Report of Grapevine red blotch-associated virus in Archival Grapevine Material From Sonoma County. Calif Plant Dis 99:895-895. https://doi. org/10.1094/PDIS-12-14-1252-PDN

Al Rwahnih M, Rowhani A, Golino DA, Islas CM, Preece JE, Sudarshana MR (2015b) Detection and genetic diversity of Grapevine red blotchassociated virus isolates in table grape accessions in the National Clonal Germplasm Repository in California. Can J Plant Pathol 37:130-135

Bahder BW, Zalom FG, Jayanth M, Sudarshana MR (2016a) Phylogeny of Geminivirus Coat Protein Sequences and Digital PCR Aid in Identifying Spissistilus festinus as a Vector of Grapevine red blotch-associated virus. Phytopathology ${ }^{\circledR} 106: 1223-$ 1230. https://doi.org/10.1094/phyto-03-16-0125-fi

Bahder BW, Zalom FG, Sudarshana MR (2016b) An evaluation of the flora adjacent to wine grape vineyards for the presence of alternative host plants of grapevine red blotch-associated virus. Plant Dis 100:1571-1574. https://doi.org/10.1094/ PDIS-02-16-0153-RE

Bankevich A et al (2012) SPAdes: a new genome assembly algorithm and its applications to single-cell sequencing. J Comput Biol J Comput Mol Cell Biol 19:455-477. https://doi.org/10.1089/cmb.2012.0021

Blanco-Ulate B et al (2017) Red blotch disease alters grape berry development and metabolism by interfering with the transcriptional and hormonal regulation of ripening. J Exp Bot 68:12251238. https://doi.org/10.1093/jxb/erw506

Calvi BL (2011) Effects of red-leaf disease on Cabernet sauvignon at the oakville experimental vineyard and mitigation by harvest delay and crop adjustment University of California, Davis

Camacho C, Coulouris G, Avagyan V, Ma N, Papadopoulos J, Bealer K, Madden TL (2009) BLAST+: architecture and applications. BMC Bioinform 10:421. https://doi.org/10.1186/1471-2105-10-421

Cieniewicz EJ, Perry K, Fuchs M (2017) Grapevine red blotch: molecular biology of the virus and management of the disease. In Springer (ed) Grapevine Viruses: Molecular Biology, Diagnostics and Management

Fahrentrapp J, Schumacher P, Viret O, J.-L. S, Burger G, Hardegger M (2015) Grapevine germplasm collections of Switzerland Vitis 54

Flasco M et al (2021) Grapevine red blotch virus is transmitted by the three-cornered alfalfa hopper in a circulative, nonpropagative mode with unique attributes Phytopathology® 0:null. https://doi. org/10.1094/phyto-02-21-0061-r

Fuchs M (2020) Grapevine viruses: a multitude of diverse species with simple but overall poorly adopted management solutions in the vineyard. J Plant Pathol 102:643-653. https://doi.org/10.1007/ s42161-020-00579-2

Gasperin-Bulbarela J, Licea-Navarro AF, Pino-Villar C, HernándezMartínez R, Carrillo-Tripp J (2019) First report of grapevine red 
blotch virus in Mexico. Plant Dis 103:381-381. https://doi.org/ 10.1094/pdis-07-18-1227-pdn

Krenz B, Thompson JR, Fuchs M, Perry KL (2012) Complete genome sequence of a new circular DNA virus from grapevine. J Virol 86:7715-7715. https://doi.org/10.1128/Jvi.00943-12

Krenz B, Thompson JR, McLane HL, Fuchs M, Perry KL (2014) Grapevine red blotch-associated virus is Widespread in the United States. Phytopathology 104:1232-1240. https://doi.org/10.1094/ phyto-02-14-0053-r

Lanciano S, Carpentier M-C, Llauro C, Jobet E, Robakowska-Hyzorek D, Lasserre E et al (2017) Sequencing the extrachromosomal circular mobilome reveals retrotransposon activity in plants. PLoS Genet 13(2): e1006630. https://doi.org/10.1371/journal.pgen. 1006630

Levin AD, KC AN (2020) Water deficits do not improve fruit quality in grapevine red blotch virus-infected grapevines (Vitis vinifera L.) Front Plant Sci 11. https://doi.org/10.3389/fpls.2020.01292

Li H, Durbin R (2009) Fast and accurate short read alignment with Burrows-Wheeler transform. Bioinformatics 25. https://doi.org/ 10.1093/bioinformatics/btp324

Lim S, Igori D, Zhao F, Moon JS, Cho IS, Choi GS (2016) First report of grapevine red blotch-associated virus on grapevine in Korea. Plant Dis 100:1957-1957. https://doi.org/10.1094/ PDIS-03-16-0283-PDN

Luna F, Debat H, Moyano S, Zavallo D, Asurmendi S, Gomez-Talquenca $S$ (2019) First report of grapevine red blotch virus infecting grapevine in Argentina. J Plant Pathol 101:1239-1239. https://doi.org/ 10.1007/s42161-019-00298-3

Malembic-Maher S et al (2020) When a Palearctic bacterium meets a Nearctic insect vector: Genetic and ecological insights into the emergence of the grapevine Flavescence doree epidemics in Europe. PLoS Pathog 16:e1007967. https://doi.org/10.1371/journ al.ppat. 1007967

Maree HJ, Fox A, Al Rwahnih M, Boonham N, Candresse T (2018) Application of HTS for routine plant virus diagnostics: state of the art and challenges. Front Plant Sci 9. https://doi.org/10.3389/ fpls.2018.01082

Marwal A, Kumar R, Paul Khurana SM, Gaur RK (2019) Complete nucleotide sequence of a new geminivirus isolated from Vitis vinifera in India: a symptomless host of grapevine red blotch virus. Virusdisease 30:106-111. https://doi.org/10.1007/ s13337-018-0477-x

Massart S et al (2017) A framework for the evaluation of biosecurity, commercial, regulatory, and scientific impacts of plant viruses and viroids identified by NGS technologies. Front Microbiol 8. https:// doi.org/10.3389/fmicb.2017.00045
Perry KL, McLane H, Hyder MZ, Dangl GS, Thompson JR, Fuchs MF (2016) Grapevine red blotch-associated virus is present in free-living Vitis spp. proximal to cultivated grapevines. Phytopathology 106:663-670. https://doi.org/10.1094/phyto-01-16-0035-r

Perry KL, McLane H, Thompson JR, Fuchs M (2017) A novel grablovirus from non-cultivated grapevine (Vitis sp.) in North America. Arch Virol. https://doi.org/10.1007/s00705-017-3567-y

Poojari S, Lowery DT, Rott M, Schmidt AM, Úrbez-Torres JR (2017) Incidence, distribution and genetic diversity of Grapevine red blotch virus in British Columbia. Can J Plant Pathol nullnull. https://doi.org/10.1080/07060661.2017.1312532

Reynard J-S, Brodard J, Dubuis N, Zufferey V, Schumpp O, Schaerer S, Gugerli P (2017) Grapevine red blotch virus: Absence in Swiss vineyards and analysis of potential detrimental effect on viticultural performance. Plant Dis 102:651-655. https://doi.org/10. 1094/PDIS-07-17-1069-RE

Reynard JS, Gugerli P (2012) Current status of major grapevine viruses in La Côte vineyards of Switzerland. Proc 17th Congr Int Counc Study Virus Virus-like Dis Grapevine (ICVG), Davis, US:74-75

Reynard JS, Heller M, Hall M, Debonneville C (2018) Development of a quantitative PCR assay for the detection of Grapevine Red Blotch Virus. Proc 19th Congr Int Counc Study Virus Virus-like Dis Grapevine (ICVG), Davis, US:74-75

Ricketts KD et al (2017) Mitigating the economic impact of grapevine red blotch: optimizing disease management strategies in U.S. vineyards. Am J Enol Vitic 68:127-135. https://doi.org/10.5344/ ajev.2016.16009

Sudarshana MR, Perry KL, Fuchs MF (2015) Grapevine red blotchassociated virus, an emerging threat to the grapevine industry. Phytopathology 105:1026-1032. https://doi.org/10.1094/ phyto-12-14-0369-fi

Wick RR, Judd LM, Gorrie CL, Holt KE (2017) Unicycler: resolving bacterial genome assemblies from short and long sequencing reads. PLoS Comput Biol 13:e1005595. https://doi.org/10.1371/ journal.pcbi.1005595

Yepes LM, Cieniewicz E, Krenz B, McLane H, Thompson JR, Perry KL, Fuchs M (2018) Causative role of grapevine red blotch virus in red blotch disease. Phytopathology® 108:902-909. https://doi. org/10.1094/PHYTO-12-17-0419-R

Zhang Y, Singh K, Kaur R, Qiu WP (2011) Association of a novel DNA virus with the grapevine vein-clearing and vine decline syndrome. Phytopathology 101:1081-1090. https://doi.org/10.1094/ Phyto-02-11-0034

Publisher's Note Springer Nature remains neutral with regard to jurisdictional claims in published maps and institutional affiliations. 